why he also is not taught something about these strange and beautiful works of God, and something of the science which investigates them, instead of the mispronounced Latin and Greek, in learning which (and most imperfectly) he spends the ten or twelve golden years of youth. He will receive for answer (or rather he will soon learn to answer himself) that those who have the monopoly of education know nothing of these matters, and therefore cannot teach them; while those who do know about them are not asked to teach them, because they will not pay in an examination. But that discovery may make him resolve, for the sake of his children or his younger brothers, to do what in him lies when he grows up, to alter radically the course of instruction now pursued in almost every boys' school in these islands; in which case this book, and others like it, will not have been published in vain.

C. KINGSLEY

\section{BARFF'S HANDBOOK OF CHEMISTRY}

An Introduction to Scientific Chemistry; designed for the use of Schools, and Candidates for University Matriculation Examinations. By F. S. Barff, M.A. Second Edition. Fcap. Svo. pp. xv. and 315, with woodcuts, price 4s. (London: Groombridge.)

THE rapid progress of experimental discovery is in itself an obstacle to the elementary teaching of any scientific subject. Nowhere has the truth of this observation been more frequently attested than in chemistry, a science. which, during the present century, has had a more brilliant, or at least a more active, career than any of its old companions. We cannot, therefore, be surprised that the superior attractions of research have so far had a depreciating influence on the dogmatic department of this study, that many chemical manuals are meagre, partial, or unsystematic. It is true that a large number of such books has appeared during the last few years, under the powerful stimulus of an increasing demand for chemical education; but their general character is such as we have assigned, and the composition of a treatise for the use of school-boys seems to have been in many cases shelved, as either too humble or too great a task for an author:

Such considerations induce us to welcome very cordially the little handbook which Mr. Barff has just republished. The first edition must be too well known, and too fresh in the memory of many of our readers to render any detailed reference to the present one necessary. The writer's efforts have evidently been directed towards attaining as much as possible of both clearness and brevity in exposition; but his tendency to avoid speculative assumptions is still more meritorious. No one is more sceptical than a boy; no one more diffcult to convince by experiment of the truth of a theory. The teacher will therefore economise his time in the most useful manner by putting before his class only the simpler practical illustrations in which he knows he can succeed, and but a few of the most general and securely established laws. Hence Mr. Barff has boldly, but very judiciously, postponed the entire discussion of formulae and symbols to the concluding portion of his work, using in its former part only absolute units of weight and measure-which, of course, have the advantage over the usual abstract numbers, that an audience can see and handle them. The nomenclature is that first systematised by Berzelius, and introduced into this country by Professor Williamson; it has also been adopted of late in the examinations of the University of London.

The method of imparting elementary instruction in chemistry is, as we have indicated, neither mature nor on the point of attainment. But whatever course may ultimately be decided upon, we can hardly doubt that it will include Mr. Barff's fundamental principle. Meanwhile this little volume, with its business-like spirit and undeniable accomplishment of its design, deserves the general and hearty commendation of teachers.

\section{E. J. Mills}

\section{OUR BOOK SHELF}

Contribution to Climatology.--Klimatologische Beiträge. By Professor A. W. Dove. (Berlin, I 869.)

ISOTHERMAL Charts like those published by Professor Dove in I 864 derive their chief interest from the fact that they permit a birds'-eye view of the great climatological features of the globe, but they are of comparatively little value to the meteorologist, unless accompanied by the numerical data on which they are founded. These are now supplied by the publication of the present volume, which, however, contains also a great deal of matter of interest to the intellectual community generally. The introductory remarks to the tables on the climate of Western Europe, and on non-periodical meteorological phenomena, will show that the distinguished author has just claims to be considered the greatest master of mieteorological generalisations.

B. L.

Wonders of Italian Art.--By Louis Viardot. Small 8vo.

Pp. 257. Illustrated with photographs and engravings. (Sampson Low \& Co.)

If photographs were not children of the sun, and if artists were not sometimes-like Leonardo da Vinci-men of science, and would always work the better for a knowledge of it, and if scientific men were not among those who can most highly appreciate works of art, this book would hardly come within our programme. It is a beautiful book, full of beautiful photographs and engravings of the best and most typical pictures of the Italian school, and one altogether refreshing to look upon. We should also add, that it is translated from the "Bibliothèque des Merveilles," which contains so many works on science.

Astronomical Publications.-I. Astronomische Mittheillungen von der Königlischen Sternwarte zu Göttingen.

(Göttingen, 1869.) 2. Sammlung von Hilfstafeln der

Berliner Sternzearte. By W. Foerster. (Berlin, I869.)

THE first publication is an account of some recent astronomical labours at the Observatory in Göttingen, and contains the results of observations with the meridian circle in zone $0^{\circ}$ and $1^{\circ}$, made in accordance with the well-known scheme of a zone revision so successfully initiated and established by English and Continental astronomers. The volume, which deserves in every respect the special attention of star observers, contains the mean places of stars up to the ninth magnitude, reduced to $1875^{\circ} \mathrm{O}$. A new method of calculating the determinations of time, originally proposed by Gauss, has been for the first time made use of by the observers. It is shown at page ix. of the Introduction, and will be found of the highest merit.

The Berlin publication contains a set of tables for the routine business of the Observatory. Although calculated with reference to the local circumstances of the Berlin establishment, they are likely to be instructive elsewhere, their arrangement being extremely compact and at the same time lucid. 